\title{
Exploring Tenor Configuration in Legislative Members' Discourse
}

\author{
Humaizi* \\ Faculty of Social and Political Sciences \\ Universitas Sumatera Utara \\ Medan, Indonesia \\ humaizi@usu.ac.id
}

\author{
Siti Hazzah Nur R \\ Faculty of Social and Political Sciences \\ Universitas Sumatera Utara \\ Medan, Indonesia \\ sitihazzah.ap@gmail.com
}

\author{
Muhammad Yusuf \\ Faculty of Cultural Sciences \\ Universitas Sumatera Utara \\ Medan, Indonesia \\ yusuf_my@usu.ac.id
}

\begin{abstract}
This study aims at discovering the employment of tenor-configuration, how it is realized in linguistic features, and why it is realized as they are in an interaction involving legislative members. This study utilized qualitative content analysis. The data were taken from the interaction among the legislative members of the House of Representatives of Medan during the working meeting with the mayor of Medan city in acknowledging the budget in 2020 . The data were in the form of transcripts of utterances. Having analyzed the data, it is found that there are four types of tenor configuration. The type [formal/unequal/positive/infrequent] becomes the dominant type totaling to $56.40 \%$. The data show that the formality used is formal, the status is unequal and equal, the affect is positive and negative, while the contact is infrequent. The formality is observable since the meeting is conducted in a formal situation. Then, the unequal status is identified since the members address other interlocutors by using addressing terms, and the equal status is recognized through the use of pronouns such as 'we'. The positive affect is signaled by the use of positive tone words, while the negative affect is signaled by the use of negative tone words. The contact is infrequent since the formal language is used during the meeting. The use of those configurations is acceptable since they meet in a formal setting attending by the members of the House of Representatives, mayor-deputy mayor, and other parties. Besides, positive and negative affect were employed as the evaluation of the government's work.
\end{abstract}

Keywords-tenor configuration, legislative members, discourse

\section{INTRODUCTION}

The interaction that the people made is built to fulfill their needs. In doing it, they utilize language as a means to build a relationship networking (Sari, Saragih, \& Bahri, 2017). Language functions as the bridge for interaction that allows people to express themselves in terms of status, social, and individual attitudes. These all include participation in linguistic interaction (Halliday \& Matthiessen, 2004). During the interaction, people use words that fit the situation to avoid miscommunication and to deliver the messages effectively.

Discourse, under the relational view of language, has to do not only with language but also the social process (Kanwal \& García, 2019). Context of situation or register in systemic functional linguistics (henceforth SFL) covers the areas of field, tenor and mode (Eggins, 2004). These areas play their role in a situation at a time of language use and possess direct and significant impacts on the type of produced language. It implies the fact that language variation appears based on the context of the situation (Eggins, 2004). Field covers the topic of situation. Mode deals with who takes part and where the situation takes place. Meanwhile, tenor deals with the social relationship and role played by addressee and addresser. Text or discourse is produced from the interaction and there is no discourse without participants.

The tenor analysis is discussed in the area of interpersonal meaning dealing with the observation of the interaction between the speaker-listener; influence behavior of speaker, and how the speaker performs their viewpoint (Halliday, 1994). Furthermore, people create their linguistic choices during interaction based on the situation (Koussouhon \& Tchibozo-Laine, 2016). Tenor observes how a participant cooperates with another participant to keep the communication process.

In the political concept, language is employed as a tool to achieve the politician's goals and interests (Al Rassam, 2010). Words are always considered to own powerful effect such creating or provoking listeners' feeling to judge a phenomenon as praiseworthy or blameworthy, as well as touching the hearts of the hearers (Mazlum \& Afshin, 2016), affecting their society and nations (Elshibaeva, 2017), and being exploited as manipulative linguistic strategy which serves concrete (ideological) goals (Amaghlobeli, 2018). In addition, Sharndama (2015) argues that political discourse (PD) is linked to either the struggle for power or the maintenance/control of it. It means that political discourse is powerful to obtain the politicians' goal, and can be utilized as a communicative act participant of which try to give specific meanings.

Political discourse in this era is seen as a subject of interdisciplinary research (Kirvalidze \& Samnidze, 2016). It is proven by many scholars' work in this subject. Observing the linguistic features in the PD, Kenzhekanova (2015) concludes that PD of mass media appears as the independent communicative phenomenon. Abdulameer, Noor, \& Nasser (2019) apply the transitivity system to analyze 80 political 
articles in Eastern and Western online news. They conclude that verbal, material and relational processes are dominant while the behavioural process is less dominant. They believe that material and verbal processes are effective to present the social actor's statement. Otieno (2019) explore PD in Kenya from the metaphorical aspect by applying the conceptual metaphor theory (CMT) and critical metaphor analysis (CMA). He concludes that positive and negative axiological values are present in the data. Furthermore, he states that metaphor expresses exclusion and hence disunity. The other research conducted by Alduhaim (2019) provides a comparison of the features of PD in English and Arabic. Utilizing mixed-method research design, he concludes that some features are commonly found in English and Arabic political discourse, such as intertextuality, repetition and the use of pronouns. Those researches are obviously different from the research that this study in terms of the scope that is analyzed, and the method used.

The language used by politicians is an interesting phenomenon to be explored. How the legislative members (LMs) which are chosen through the election process use the language is crucial for maintaining their relationship with their constituents. Their language can be observed by applying tenor theory to see the formality, the status, the affect, and the contact happen among the speakers. The LMs sometimes seem not to recognize that they show various configurations of tenor through their discourses. There will be some configuration types possible to happen such as formal language is used but the negative affect is shown or even positive affect on some occasion. The use of negative affect possibly offends or hurts the audiences. That is why the LMs should be careful in uttering their discourse.

Regarding the importance of analyzing tenor in PD, this paper attempts to discover how the tenor configuration is employed, how it is realized, and why it is realized as they are in LM's discourse. It is hoped that the findings are advantageous in enriching the horizon specifically the application of SFL theory in political discourse, and it can be as constructive suggestion for the politicians in communicating with their constituents and the listeners of their discourse, and as a precaution of conflict and controversy resulted from their statement.

\section{REVIEW OF LITERATURE}

\section{A. Interpersonal Function in SFL}

Systemic Functional Linguistics (SFL) deals with the study on the language as a source of making meaning (Zein, Sinar, Nurlela, \& Yusuf, 2019). In SFL, it is believed that language has three prominent kinds of meanings simultaneously regarded as the metafunction of language (Halliday \& Matthiessen, 2004) covering ideational, interpersonal, and textual functions. Eggins \& Slade (1997) argue that interpersonal meaning views the roles and relationship which involves looking at what kinds of role relations are established through talk, what attitudes interactants express to and about each other, what kinds of things they find funny, and how they negotiate to take turns, etc. In short, as one of metafunction of language, interpersonal meaning sees clause as exchanged among the interactants or speakers.

\section{B. Context of Situation}

Text owns the context accompanying it. One of the contexts is the social context. In the SFL perspective, the social context is categorized as a non-linguistic context or an external context. It is regarded as any physical environment which is seen, realized or interpreted in relation to human beings or simply termed as a social context (Saragih, 2014). Moreover, this context includes a large area in SFL, and it is interpreted as being constituted by three elements, namely the context of the situation (register), culture (genre) and ideology. The context of the situation is technically termed as a register that varies according to the use of language in a different situation (Sari et al., 2017) and comprises of field, tenor, and mode.

\section{Tenor}

Tenor is included as one of the aspects of the context of the situation and it is realized through interpersonal function. Tenor has four elements covering formality, status, contact, and affective involvement. It is recognizable from mood, modality, evaluation, and lexical or grammatical choices (Eggins, 2004; Sari et al., 2017).

First, formality deals with behavior related to the condition in which interactions happen. Formality has two possibilities; formal and informal situation. A formal situation is defined as a situation where interaction behavior is predetermined. Otherwise, an informal situation provides no predetermined interaction behavior.

The second, status refers to the power relations of participants in interactions. The status can be divided into two i.e. equal and unequal status. A person has power if he can make others do or not do what he wants.

The third is the affect. It deals with the positive or negative feelings of the writer/speaker realized in the discourse. Moreover, it also shows the passion for the emotional aspects of the participants in the interaction such as the likeness feelings during the interaction. Positive affect is signaled by praising, using positive tone words, etc. On the other hand, negative affect is signaled by expressions of negative tone words. The last, contact refers to the frequency of interactions that occur frequently or rarely. The frequent contact is normally signaled by the use of common coding. Conversely, infrequent contact is signaled by the employment of formal language.

It is possible that in delivering the utterances, the combination of tenor may be different. The type of tenor used 
will be different depending on the context surrounding the discourse. The formal language can be used even though the contact is frequent, and positive affect can appear along with infrequent contact. Saragih (2014) states that the system network of tenor can be figured out into 16 possibilities of combination based on the situation surrounding the discourse.

\section{METHOD}

This study utilized qualitative content analysis as the research design. The data were taken from the utterances of legislative members of the House of Representatives of Medan (Dewan Perwakilan Rakyat Daerah henceforth DPRD) during the working meeting with the mayor of Medan in acknowledging the budget of the city of Medan for 2020 on $29^{\text {th }}$ June 2019. In DPRD Medan, there are 50 members elected from the general election held in 2014 (Humaizi, Yusuf, \& Sinaga, 2019).

The data analysis technique applied was the interactive model proposed by Miles, Huberman, \& Saldana (2014). The first step was data condensation. There were 5 steps done namely the selecting, the abstracting, the focusing, simplifying and the transforming. The utterances were analyzed based on tenor (formality, status, affect, and contact) (Eggins, 2004). Simplifying is done by giving codes to all data. After that, the ranking was done based on the result of the analysis. Secondly, the data display is that the data were transformed and displayed in the table. In the last step, the conclusion was drawn based on the analysis.

\section{RESULT}

The analysis presents that there are four types of tenor configuration realized in the data namely: [formal/unequal/positive/infrequent] (FUPI), [formal/equal/positive/infrequent] (FEPI), [formal/unequal/negative/infrequent] (FUNI), and the last one is [formal/equal/negative/infrequent] (FENI). Then, the dominant type of tenor configuration is FUPI.

The realization of the tenor is seen from four aspects namely formality, status, affect, and status as the following.

\section{A. Formality}

In the data, the formality realized is in a formal situation. Saragih (2014) argues that formality refers to behavior that is related to a situation in which interaction happens. It shows a formal situation since everything in the meeting has been set previously such as the regulations, the orders of speeches, factions' representatives, the attendees, and who will be honored during the meeting. Moreover, formality is also performed through the way of addressing the invited guest and participants such as the following example.

"Honorable the mayor of Medan, vice-mayor of Medan, the head, vice, all legislative members, invited guests, journalists, and all participants."
This excerpt reveals that the speaker addressed the attendees based on the hierarchy of power, or top-down, starting from the mayor of Medan to all participants in the meeting room.

\section{B. Status}

The status that appeared in the discourse is equal and unequal. The unequal status is easily observed by the use of the name along with the title in addressing someone as the example below:

Saudara Walikota Medan yang terhormat (honorable the mayor of Medan)

Anggota Dewan yang terhormat (the honorable legislative members)

The phrase "the mayor of Medan" shows the title that has been mentioned by the legislative members. Then, it is also followed by the use of the phrase "the honorable legislative members." Those sentences show that status appeared in the interaction is unequal.

The equal status in the data is hinted by the use of pronoun 'we', 'our', and 'us' such as the following;

"maka perkenanlah kami menyampaikan pendapat fraksi..." (let us deliver our faction's opinion.....).

C. Affect

The positive and negative affect are performed in the data. Affect deals with the emotional aspect of the participants in interaction (Martin, 1992). The employment of positive affect is indicated by the use of endearing which is observable from the phrases used such as "the honorable participants, the happy participants, and so on."

On the other hand, the employment of negative affect in the data is clued by the use of negative tone words and phrases such as ketidakseriusan (unserious), belum memenuhi harapan (out of expectation), and tidak mencapai target (out of target).

\section{Contact}

In terms of contact, it is revealed that only the infrequent contact was applied. The contact relates to the interaction frequency. There are some characteristics of the use of infrequent contact or uninvolved contacts such as the use of the full names, standard language, and no vocative use. In the data, the vocative use, such as Bro Eldin, was not found. Instead, the LMs use the full name along with the title given, the honorable the mayor of Medan, Drs. H. T. Dzulmi Eldin, M.Si. Additionally, infrequent contact is also signaled by the use of formal language. There is no sentence or phrase such 'macam betol kali yang buat' 'it's as if you did the right job'. 


\section{DISCUSSION}

The choice of the tenor is applied to maintain good communication as well as to get the message delivered well. The tenor variation applied in LM's discourse shows that they are skillful in selecting the best diction for their listeners. The meeting involved DPRD of Medan city and the government of Medan. Therefore, the LMs need to pay attention to whom they speak to maintain good relationships. Mazlum \& Afshin (2016) address that the words or phrases used in political discourse possess enormous power. By using good and precious dictions, the politician obviously could touch the heart of the audiences, persuading them, or even provoking them.

The study has identified infrequent contacts appearing in the data. This is quite different from research conducted by Sari et al. (2017). They discovered both frequent and infrequent contacts were realized in the campaign speech. It is understandable as in the campaign speech it is possible to use slang language to insult the opponent since the situation is informal sometimes. In this case, in the meeting between the LMs and the government of Medan city, the language used is formal.

The use of word choice to show unequal status is also related to culture and politeness. The one with higher status in the Indonesian context is normally addressed based on the title given (such as the position in the organization). It is also in line with the statement clarifying that political discourse can be regarded as a culture-bound text (Esposito, 2017). The choice of the sentences such as "yang terhormat bapak walikota Medan (the honorable the mayor of Medan city)" is to perform politeness and to honor him since 'mayor' is the top position in the city organization.

Halliday \& Matthiessen (2004s) assert that one of the functions of language is to provide a medium of interaction and it allows the person to express social status, behaviors, evaluation, and others. The LMs apply both positive and negative affects to provide an evaluation of the works done by the government of Medan in the previous year. They appreciate the governments' work by using positive affect. It is performed through endearing words or phrases. This employment aims to make the mayor and his team feel glad or happy about their work. In different circumstances, the LMs becomes straightforward by using the negative affect to show the unsatisfactory job done in the previous year. It is also to show that there is something needed to be improved by the mayor in the following year since the budget approved should be allocated effectively. In conclusion, those categories can happen due to the nature of the context.

\section{CONCLUSION AND SUGGESTION}

After analyzing the data, it is found that there are four types of tenor configuration realized in the data namely: [formal/unequal/positive/infrequent], [formal/equal/positive/infrequent],

[formal/unequal/negative/infrequent], and the last one is [formal/equal/negative/infrequenst]. The dominant configuration tenor is [formal/unequal/positive/infrequent] totaling to $56.40 \%$.

In terms of its realization, the tenor is described by four aspects. The formality used is formal. This is observable since the meeting is conducted in a formal situation. The status is portrayed in two forms: equal and unequal. The unequal status is described since the members address other interlocutors by using addressing terms such as the mayor of Medan, the head of the regional house of representative, and so on. Meanwhile, equal status is presented through the use of pronouns such as 'we, 'our', and 'us'. The affect applied is positive and negative. The affect is positive since the members used positive tone words such as the phrase 'memberi manfaat' beneficial, 'dimanfaatkan dengan baik' carefully utilized, etc. The negative affect is shown through the use of the phrase such as 'tidak dilakukan sesuai dengan harapan' outside the expectation, 'tidak mencapai target' out of the target, and 'belum melakukan langkah yang konkrit dan tegas' has not done a concrete and assertive action yet. The contact shows infrequent contact. It is illustrated by the use of formal languages during the meeting and no vocative used.

The use of those four configurations is reasonable since the meeting was conducted in formal settings including the members of the House of Representatives, mayor-deputy mayor, and other parties. Besides, positive and negative affect were employed as the evaluation of the government's work as the reasoning to approve the budget planning by the government of Medan city.

Since this research is limited to the configuration of the tenor used by LMs, further studies exploring PD through other functional features such as textual and experiential function, the metaphor used in political discourse, and the role of gender in political discourse are suggested.

\section{ACKNOWLEDGMENT}

The writers would like to thank the research institute (lembaga penelitian) of Universitas Sumatera Utara for Talenta grant 2019, no: 4167/UN5.1.R/PPM/2019, dated on $1^{\text {st }}$ April, 2019. Then, the sincere gratitude is addressed to DPRD Kota Medan for permitting the research.

\section{REFERENCES}

Abdulameer, A. H., Mohd Noor, S. N. F., \& Nasser, W. K. (2019). Systemic functional linguistics of political articles in eastern and western online news. Humanities \& Social Sciences Reviews, 7(5), 2431. https://doi.org/10.18510/hssr.2019.753

Al Rassam, E. M. (2010). Analyzing political discourse: Towards a pragmatic approach. College of Basic Education Researchers Journal, 10(1), 528-552. 
Alduhaim, A. (2019). A comparative study of political discourse features in English and Arabic. International Journal of English Linguistics, 9(6), 148-159. https://doi.org/10.5539/ijel.v9n6p148

Amaghlobeli, G. (2018). Types of political discourses and their classification. Journal of Education in Black Sea Region, 3(1), 18-24. https://doi.org/10.31578/jebs.v3i1.117

Eggins, S. (2004). An introduction to systemic functional linguistics (2nd ed.). New York: Continuum.

Eggins, S., \& Slade, D. (1997). Analysing casual conversation. London: Equinox.

Elshibaeva, K. Z. (2017). Strategic communication of political discourse. Atlas Journal, 3(3), 1-7. https://doi.org/10.31568/atlas.14

Esposito, E. (2017). The mother's picong: A discursive approach to gender, identity and political leadership in Trinidad and Tobago. Discourse \& Society, 28(1), 24-41. https://doi.org/10.1177/0957926516676692

Halliday, M. A. K. (1994). An introduction to functional grammar (2nd ed.). London: Edward Arnold.

Halliday, M. A. K., \& Matthiessen, C. M. I. M. (2004). An introduction to functional grammar (3rd ed.). London: Hodder Education.

Humaizi, Yusuf, M., \& Sinaga, R. S. (2019). The interest pattern of ethnic groups as supporters: A case study of pilkada of Medan city in 2015. Intellectual Discourse, 27(1), 269-283.

Kanwal, S., \& García, M. I. M. (2019). Representation of gender through framing: A critical discourse analysis of Hillary Clinton's selected speeches. International Journal of English Linguistics, 9(2), 321-331. https://doi.org/10.5539/ijel.v9n2p321

Kenzhekanova, K. K. (2015). Linguistic features of political discourse. Mediterranean Journal of Social Sciences, 6(6), 192-199. https://doi.org/10.5901/mjss.2015.v6n6s2p192

Kirvalidze, N., \& Samnidze, N. (2016). Political discourse as a subject of interdisciplinary studies. Journal of Teaching and Education, 5(1), 161-170.
Koussouhon, L. A., \& Tchibozo-Laine, I. (2016). Tenor and interpersonal meaning in Amma Darko's fiction: A feminist approach. Studies in English Language Teaching, 4(4), 650-669. https://doi.org/10.22158/selt.v4n4p650

Martin, J. R. (1992). English text: System and structure. Amsterdam: John Benjamins.

Mazlum, F., \& Afshin, S. (2016). Evaluative language in political speeches: A case study of iranian and american presidents' speeches. International Journal of Linguistics, 8(4), 166-183. https://doi.org/doi:10.5296/ijl.v8i4.9398

Miles, M. B., Huberman, A. M., \& Saldana, J. (2014). Qualitative data analysis: A methods sourcebook (3rd ed.). California: Sage Publication Inc.

Otieno, R. F. (2019). Metaphors in political discourse in Kenya: Unifying or divisive? International Journal of Learning and Development, 9(2), 62-82. https://doi.org/10.5296/ijld.v9i2.14918

Saragih, A. (2014). Discourse analysis: A study on discourse based on systemic functional linguistic theory. Medan: Unimed Press.

Sari, Y. N., Saragih, A., \& Bahri, S. (2017). Tenor configuration in campaign speeches of two democratic party presidential candidates 2016. Linguistica, 6(4). https://doi.org/10.24114/jalu.v6i4.7598

Sharndama, E. C. (2015). Political discourse: A critical discourse analysis of president Muhammadu Buhari's inaugural speech. European Journal of English Language and Linguistics Research, 3(3), 1224

Zein, T. T., Sinar, T. S., Nurlela, N., \& Yusuf, M. (2019). The Incomplete linguistic features and schematic structure in EFL university students' narrative texts. JETL (Journal Of Education, Teaching and Learning), 4(1), 203-209. https://doi.org/10.26737/jetl.v4i1.675 